\title{
Regulation of bacterial methane oxidation: transcription of the soluble methane mono- oxygenase operon of Methylococcus capsulatus (Bath) is repressed by copper ions
}

\author{
Allan K. Nielsen, ${ }^{1}$ Kenn Gerdes, ${ }^{1}$ Hans Degn $^{2}$ and J. Colin Murrell ${ }^{3}$ \\ Author for correspondence: J. Colin Murrell. Tel: +44 1203 523553. Fax: +44 1203523568. \\ e-mail: CM@dna.bio.warwick.ac.uk
}

1 Department of Molecular Biology and 2Department of Biochemistry, Odense University, DK-5230 Odense M, Denmark

3 Department of Biological Sciences, University of Warwick, Coventry CV4 7AL, UK

\begin{abstract}
Methane is oxidized to methanol by the enzyme methane mono-oxygenase (MMO) in methanotrophic bacteria. In previous work, this multicomponent enzyme system has been extensively characterized at the biochemical and molecular level. Copper ions have been shown to irreversibly inhibit MMO activity in vivo and in vitro, but the effect of copper ions on transcription of the genes encoding the soluble (cytoplasmic) MMO (sMMO) has not previously been investigated. To examine more closely the regulation of bacterial methane oxidation and to determine the role of copper in this process, we have investigated transcriptional regulation of the sMMO gene cluster in the methanotrophic bacterium Methylococcus capsulatus (Bath). Using Northern blot analysis and primer extension experiments, it was shown that the six ORFs of the SMMO gene cluster are organized as an operon and the transcripts produced upon expression of this operon have been identified. The synthesis of these transcripts was under control of a single copper-regulated promoter, which is as yet not precisely defined.
\end{abstract} Keywords: Metbylococcus capsulatus (Bath), methanotrophs, smmo genes, mRNA, copper
ions

\section{INTRODUCTION}

The obligate methane-oxidizing bacteria, methanotrophs, utilize methane as their sole source of carbon and energy. The first step in the methane oxidation pathway is catalysed by the enzyme methane mono-oxygenase (MMO), which converts methane to methanol in an oxygen- and NADH-dependent reaction. Methanol is then oxidized by methanol dehydrogenase to formaldehyde, which is assimilated into cellular biomass. A proportion of the formaldehyde is further oxidized via formate to carbon dioxide to provide reducing power for biosynthesis and the initial oxidation of methane (Anthony, 1986).

Whereas all methanotrophs appear to express a membrane-bound, particulate MMO (pMMO), a soluble enzyme complex (sMMO) has been found in only a few methanotrophs. The type of enzyme expressed seems to

Abbreviations: s/pMMO, soluble/particulate methane mono-oxygenase; NMS, nitrate mineral salts. be dependent upon the availability of copper ions in the growth medium; pMMO activity is observed when organisms are grown at a high copper ion: biomass ratio, whereas organisms subjected to copper deficiency contain sMMO (Scott et al., 1981a, b; Stanley et al., 1983; Koh et al., 1993; Nakajama et al., 1992; Pilkington \& Dalton, 1991). sMMO has a broader substrate range than the pMMO. It catalyses the oxidation of a wide range of aliphatic, alicyclic and aromatic hydrocarbons (Colby \& Dalton, 1978; Stirling \& Dalton, 1979).

The sMMO complex from the type $\mathrm{X}$ methanotroph Metbylococcus capsulatus (Bath) has been extensively characterized (Colby \& Dalton, 1979; Green \& Dalton, 1985; Woodland \& Dalton, 1989; Dalton et al., 1993). sMMO consists of three components. Protein $A$, the hydroxylase component, comprises three subunits, $\alpha, \beta$ and $\gamma$, of 60,45 and $20 \mathrm{kDa}$, respectively (Woodland \& Dalton, 1989). Protein $\mathrm{B}$ is a protein of $16 \mathrm{kDa}$ and is thought to act as a modulator of the $\mathrm{MMO}$ reaction by forming a specific complex with the hydroxylase component (Green \& Dalton, 1985; Liu \& Lippard, 1991; Fox et al., 1991; Lipscomb, 1994). Protein C is a $39 \mathrm{kDa}$ iron-sulfur 
flavoprotein responsible for shuttling electrons from NADH to Protein A of sMMO (Lund \& Dalton, 1985; Lund et al., 1985). The sMMO from the type II methanotroph Metbylosinus trichosporium OB3b has also been extensively characterized. The sMMO from this related organism was resolved into three components with similar properties to the components of the sMMO from M. capsulatus (Bath) (Fox et al., 1989, 1990).

The structural genes encoding the sMMO components of Methylococcus capsulatus (Bath) (smmo) have been cloned and sequenced (Stainthorpe et al., 1989, 1990). These genes were found to be clustered in the order mmoX, $m m o Y, m m o B, m m o Z$, orf $Y$ and $m m o C$ and encode $\alpha, \beta$, Protein $B, \gamma$, a protein of unknown function and Protein $\mathrm{C}$, respectively. This clustering of the sMMO structural genes has also been found in the type II methanotroph Methylosinus trichosporium OB3b (Cardy et al., 1991a, b).

Relatively little is known, however, about the regulation of this gene cluster since the genetics of methanotrophs is relatively poorly developed and there are few efficient systems for gene transfer or mutagenesis in these organisms (reviewed in Murrell, 1994). Similarly, expression studies on sMMO using primer extension and Northern blot analyses have been hampered by difficulties in the preparation of good quality $\mathrm{mRNA}$ from methanotrophs (J. C. Murrell \& D. L. N. Cardy, unpublished observations).

The switch from expression of the soluble to the particulate enzyme complex in Metbylococcus capsulatus (Bath) has been shown to depend on the concentration of copper ions in the growth medium. The switch is correlated with the formation of extensive intracytoplasmic membranes and the MMO activity of the cells becomes entirely membrane-associated. sMMO activity is no longer detectable (Prior \& Dalton, 1985).

It is not fully understood how copper ions mediate this switch. The regulation of sMMO and $\mathrm{pMMO}$, and the role of copper in this metabolic switch, is complicated by the pleiotropic effect of this ion in methane oxidation. Copper ions are essential for pMMO activity and are believed to reside in the active site of the enzyme (Chan $e t$ al., 1993; Nguyen et al., 1994). Copper ions have also been shown to inhibit sMMO activity both in vivo and in vitro (Stanley et al., 1983; Dalton et al., 1984; Prior \& Dalton, 1985; Green et al., 1985). Finally, in addition to the inhibitory effect of copper ions on the soluble enzyme itself, it has been suggested that copper ions may have a potential role as a cofactor in transcriptional inhibition of the sMMO gene cluster of Metbylosinus trichosporium OB3b (Tsien et al., 1989).

\section{METHODS}

Bacterial strains. The type X methanotroph Metbylococcis capsulatus (Bath) was obtained from the University of Warwick culture collection. The Escherichia coli $\mathrm{K} 12$ strain $\mathrm{CSH} 50[\Delta($ lac pro)rpsL; Miller, 1972] was used as the host in DNA cloning experiments.
Growth of $\boldsymbol{M}$. capsulatus (Bath). $M$. capsulatus (Bath) was grown in continuous culture in a 2.51 working volume fermenter (LH Engineering) on a nitrate mineral salts (NMS) medium (Dalton \& Whittenbury, 1976). The chemostat was operated under oxygen limitation with methane $(20 \%, \mathrm{v} / \mathrm{v}$, in

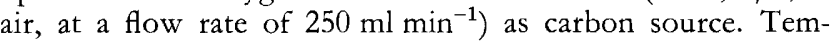
perature and $\mathrm{pH}$ were maintained at $45^{\circ} \mathrm{C}$ and 6.8 , respectively. A dilution rate $(D)$ of $0.05 \mathrm{~h}^{-1}$ was used and at steady-state, the dry weight of the culture was $1.5-2.0 \mathrm{mg} \mathrm{m}^{-1}$. To ensure that $M$. capsulatus cells were only expressing sMMO, $\mathrm{Cu}^{2+}$ was omitted from the trace elements solution of NMS. To confirm the presence or absence of sMMO, the assay of Brusseau $e t$ al. (1990), which measures the oxidation of naphthalene to naphthol by sMMO, but not pMMO, was used.

Biochemical methods. Preparation of plasmid DNA and DNA manipulations were according to Maniatis et al. (1982). In vitro RNA synthesis was performed according to the manufacturer (Promega).

\section{Construction of plasmids}

Plasmid pMX2. The upstream $2.67 \mathrm{~kb}$ EcoRI-BamHI fragment of $\mathrm{pCH} 4$ was purified from an agarose gel and ligated to the large EcoRI-BamHI fragment of pBR322 (Bolivar et al., 1977), resulting in pMO1. Thus, pMO1 contains the first 1193 nucleotides of the mmoX gene preceded by the 1477 upstream nucleotides. The $m m o X$ intragenic Pst $\mathrm{I}-$ Bam HI fragment of $0.58 \mathrm{~kb}$ was isolated from pMO1 and inserted into pGEM 3 cut with the same enzymes, resulting in pMX2. Transcription from the T7 RNA polymerase promoter, pT7, produced a singlestranded transcript complementary to mmoX-encoding mRNAs.

Plasmids pMY2, pMB1 and pMZ1. The smmo-specific fragments of plasmids $\mathrm{pMY} 2, \mathrm{pMB1}$ and $\mathrm{pMZ1}$ were generated by PCR using plasmid pCH4 as template. The primers used for PCR amplifications contained recognition sequences for the restriction enzymes $B a m \mathrm{HI}$ (upstream primer) and EcoRI (downstream primer) and after digestion with these enzymes, the DNA fragments were ligated to PGEM3 (Promega) also digested with these enzymes. The transcripts produced upon transcription from pT7 of these plasmids are described in Table 1.

Plasmid pMC2. The region covering the last 16 nucleotides of orf $Y$, the orf $Y-m m o C$ intergenic region and the first 194 nucleotides of $m m o C$ was amplified by PCR using plasmid pCH4 as template and primers with EcoRI (upstream primer) and Pst I (downstream primer) sites. After restriction of the amplified DNA fragment with these enzymes, the resulting EcoRI-Pst DNA fragment was ligated to pGEM4 (Promega) digested with the same enzymes, resulting in pMC2. Prior to use as template for in vitro generation of an orf $Y-m m o C$-specific riboprobe, plasmid pMC2 was restricted with Aat II. Thus, the resulting riboprobe covers the region from 5725 to 5831 (the last 16 nucleotides of $\operatorname{orf} Y$, the orf $Y-m m o C$ intergenic region and the first 76 nucleotides of $m m o C$ ).

Isolation of total RNA. Total RNA was isolated from $1.5 \mathrm{ml}$ aliquots of $M$. capsulatus (Bath) cells taken from a chemostat culture $\left(\mathrm{OD}_{540}\right.$ of approximately $\left.8 \cdot 0\right)$. The cells were pelleted by centrifugation in $1.5 \mathrm{ml}$ Eppendorf tubes and resuspended in $300 \mu \mathrm{l}$ of a solution containing $0.3 \mathrm{M}$ sucrose, $5 \mathrm{mg}$ lysozyme $\mathrm{ml}^{-1}$ and $0.01 \mathrm{mM}$ sodium acetate, $\mathrm{pH} 4 \cdot 5$. These aliquots were kept on ice for $10 \mathrm{~min}$ and then frozen in liquid nitrogen for $10 \mathrm{~s}$. A solution $(300 \mu \mathrm{l})$ containing $2 \%(\mathrm{w} / \mathrm{v})$ SDS and $0 \cdot 01 \mathrm{M}$ sodium acetate, $\mathrm{pH} 4.5$, was added and the aliquots were incubated for $1 \mathrm{~min}$ at $65^{\circ} \mathrm{C}$. The preparations were mixed with $0.5 \mathrm{ml}$ phenol and incubated with vigorous shaking for $3 \mathrm{~min}$ at $65^{\circ} \mathrm{C}$ and then frozen in liquid nitrogen for $10 \mathrm{~s}$. The 
Table 1. Plasmids used in this study

\begin{tabular}{|c|c|c|c|c|c|}
\hline Plasmid & $\begin{array}{l}\text { Type of } \\
\text { replicon }\end{array}$ & $\begin{array}{l}\text { Relevant } \\
\text { genotypes }\end{array}$ & $\begin{array}{c}\text { smmo co-ordinates } \\
\text { present* }\end{array}$ & $\begin{array}{c}\text { Riboprobe } \\
\text { complementary to: }\end{array}$ & Source \\
\hline pMX2 & pGEM3 & bla pT7 & $2087-2670$ & $\operatorname{mmoX}$ & This study \\
\hline pMY2 & pGEM3 & bla pT7 & $3511-4326$ & $m m o Y$ & This study \\
\hline pMB1 & pGEM3 & bla $\mathrm{p} T 7$ & $4343-4698$ & $m m o B$ & This study \\
\hline pMZ1 & pGEM3 & bla $\mathrm{p} T 7$ & $4884-5232$ & $m m o Z$ & This study \\
\hline $\mathrm{pMC2}$ & pGEM4 & bla p $\mathrm{T} 7$ & $5725-5949 \dagger$ & $o r f Y-m m o C$ & This study \\
\hline $\mathrm{pCH} 4$ & pBR325 & bla tet & $1-7187$ & - & Stainthorpe et al. (1990) \\
\hline pGEM3 & - & bla $\mathrm{p}^{\prime} \Gamma 7$ & - & - & Promega \\
\hline pGEM4 & - & bla p T7 & - & - & Promega \\
\hline
\end{tabular}

* Gene EMBL accession number, M90050.

† The riboprobe generated from pMC2 covers the region from 5725 to 5831 (see Methods).

supernatants were recovered by centrifugation for $5 \mathrm{~min}$ and the phenol extraction repeated. Finally, the RNA was extracted with $0.5 \mathrm{ml}$ phenol/chloroform $(1: 1)$ at room temperature, precipitated with $1.2 \mathrm{ml} 96 \%(\mathrm{v} / \mathrm{v})$ ethanol and $75 \mu \mathrm{l}$ sodium acetate, $\mathrm{pH} 4 \cdot 5$. The pellet was resuspended in $30 \mu \mathrm{H} \mathrm{H}_{2} \mathrm{O}$ and the concentration of nucleic acid determined by measuring the $A_{260}$ on an Ultraspec III spectrophotometer (Pharmacia).

Northern blot analysis. RNA $(10 \mu \mathrm{g})$ was dried in a vacuum drier and resuspended in $4.5 \mu \mathrm{H} \mathrm{H}_{2} \mathrm{O}, 2 \mu \mathrm{l} 5 \times$ formaldehyde gel

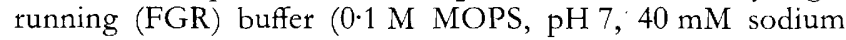
acetate, $5 \mathrm{mM}$ EDTA), $3.5 \mu \mathrm{l}$ formaldehyde $(7 \%, \mathrm{v} / \mathrm{v}$, final concentration) and $10 \mu \mathrm{l}$ formamide $(50 \%, \mathrm{v} / \mathrm{v}$, final concentration). The RNA molecules were denatured by incubation for $15 \mathrm{~min}$ at $60^{\circ} \mathrm{C}$ and separated in a $1.2 \%(\mathrm{w} / \mathrm{v}$ ) agarose gel containing $2 \cdot 2 \%$ formaldehyde which was run at $5 \mathrm{~V} \mathrm{~cm}^{-1}$ with FGR buffer as the electrophoresis buffer. The gel was then washed in $\mathrm{H}_{2} \mathrm{O}$ for $20 \mathrm{~min}$ at room temperature. Nucleic acids were transferred to a Zeta-Probe GT membrane (Bio-Rad) by overnight capillary blotting using $50 \mathrm{mM} \mathrm{NaOH}$ as the transfer buffer. The membranes were air-dried and prehybridized for $2 \mathrm{~h}$ at $42{ }^{\circ} \mathrm{C}$ in hybridization buffer $(1 \mathrm{mM} \mathrm{NaCl}, 4 \mathrm{mM}$ $\mathrm{Na}_{4} \mathrm{P}_{2} \mathrm{O}_{7} .10 \mathrm{H}_{2} \mathrm{O}, 5 \times$ Denhardt's solution, $1 \%$ SDS, $10 \%$, $\mathrm{w} / \mathrm{v}, \mathrm{PEG} 6000,50 \mathrm{mM}$ Tris $/ \mathrm{HCl}(\mathrm{pH} \mathrm{7.5})$ and $250 \mu \mathrm{g}$ yeast tRNA ml ${ }^{-1}$ ) before the ${ }^{32} \mathrm{P}$-labelled riboprobe was added. After overnight hybridization at $42^{\circ} \mathrm{C}$, membranes were washed two times for $5 \mathrm{~min}$ at room temperature in $2 \times \mathrm{SSC}$, two times for $30 \mathrm{~min}$ at $65^{\circ} \mathrm{C}$ in $0.2 \times \mathrm{SSC}, 1 \% \mathrm{SDS}$ and two times for $30 \mathrm{~min}$ at $65^{\circ} \mathrm{C}$ in $0.1 \times$ SSC before being air-dried and used for autoradiography. The $0 \cdot 24-9 \cdot 5 \mathrm{~kb}$ RNA ladder from Gibco BRL was used as molecular size standard in Northern blot experiments.

Primer extension experiments. RNA $(5 \mu \mathrm{g})$ and ${ }^{32} \mathrm{P}$-labelled primer $(15 \mathrm{ng})$ were heated for $2 \mathrm{~min}$ at $80^{\circ} \mathrm{C}$ in $5 \mu \mathrm{l}$ hybridization buffer $(100 \mathrm{mM} \mathrm{KCl}, 50 \mathrm{mM}$ HEPES, pH $7 \cdot 0)$ followed by gradual cooling to $30^{\circ} \mathrm{C}$ over a $60 \mathrm{~min}$ period. Three microlitres of a solution containing $250 \mathrm{mM}$ Tris $/ \mathrm{HCl}$,

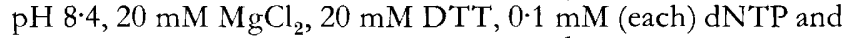
0.75 units $A M V$ reverse transcriptase $\mu)^{-1}$ (Life Sciences) was added and the mixture was incubated at $40{ }^{\circ} \mathrm{C}$ for $30 \mathrm{~min}$. The extension products were precipitated with ethanol and resuspended in $6 \mu \mathrm{l}$ formamide loading buffer, preheated at $85^{\circ} \mathrm{C}$ for $3 \mathrm{~min}$ and loaded onto a $7 \%$ polyacrylamide gel alongside a set of dideoxy sequencing reactions (Sanger et al., 1977) of plasmid pCH4 DNA with the same primer. The sequences of the primers used (in the $5^{\prime}-3^{\prime}$ direction) were:
Xp1, ATGCCCGATGACGTCACGG; Xp2, AGCCATCGGACATAACGG; Xp3, GCGGCCGCCGGAAACCTG; Xp4, TCGATCCGACCACTGCGG; Xp5, ACGCGGGCGGTGCCGCTG; Yp1, TCGGTCAGACCGCGGCGTC; orfYp1, TGGCTGAAATGCCGATTCG; MC5781, CGCCATCCTCCGTCACCG.

\section{RESULTS}

\section{Identification of sMMO-specific transcripts}

sMMO-specific transcripts were investigated by Northern blot analysis of total RNA isolated from $M$. capsulatus (Bath) cells grown in continuous culture on a nitrate mineral salts medium (Dalton \& Whittenbury, 1976). The chemostat was operated under oxygen limitation with methane as sole source of carbon and energy. sMMOexpressing cells (at high cell density) were established on copper-deficient NMS medium (i.e. with no added copper) and pMMO expressing cells were established on NMS medium containing $50 \mu \mathrm{M}$ copper sulphate. Genespecific antisense riboprobes were obtained by subcloning of intragenic regions of $m m o X, m m o Y, m m o B, m m o Z$ and $m m o C$ into pGEM3 or pGEM4 vectors, followed by in vitro transcription using the T7 RNA polymerase. The DNA fragments used for the construction of the probe plasmids are described in detail in Table 1.

Total RNA was fractionated on an agarose gel, transferred to a nylon membrane and hybridized to the ${ }^{32} \mathrm{P}$-labelled gene-specific riboprobes. Total RNA isolated from $M$. capsulatus (Bath) cells grown in the presence of $50 \mu \mathrm{M}$ copper sulphate did not hybridize to any of the probes used (not shown), which suggests that in the presence of copper, sMMO structural gene expression is switched off or repressed. Total RNA isolated from copper-depleted cultures (e.g. no added copper sulphate), however, yielded transcripts complementary to the specific gene probes used.

When the mmoX-specific gene probe was used to probe total RNA from $M$. capsulatus (Bath) grown in the absence of copper, two transcripts of approximately 1.7 and $4.0 \mathrm{~kb}$ 


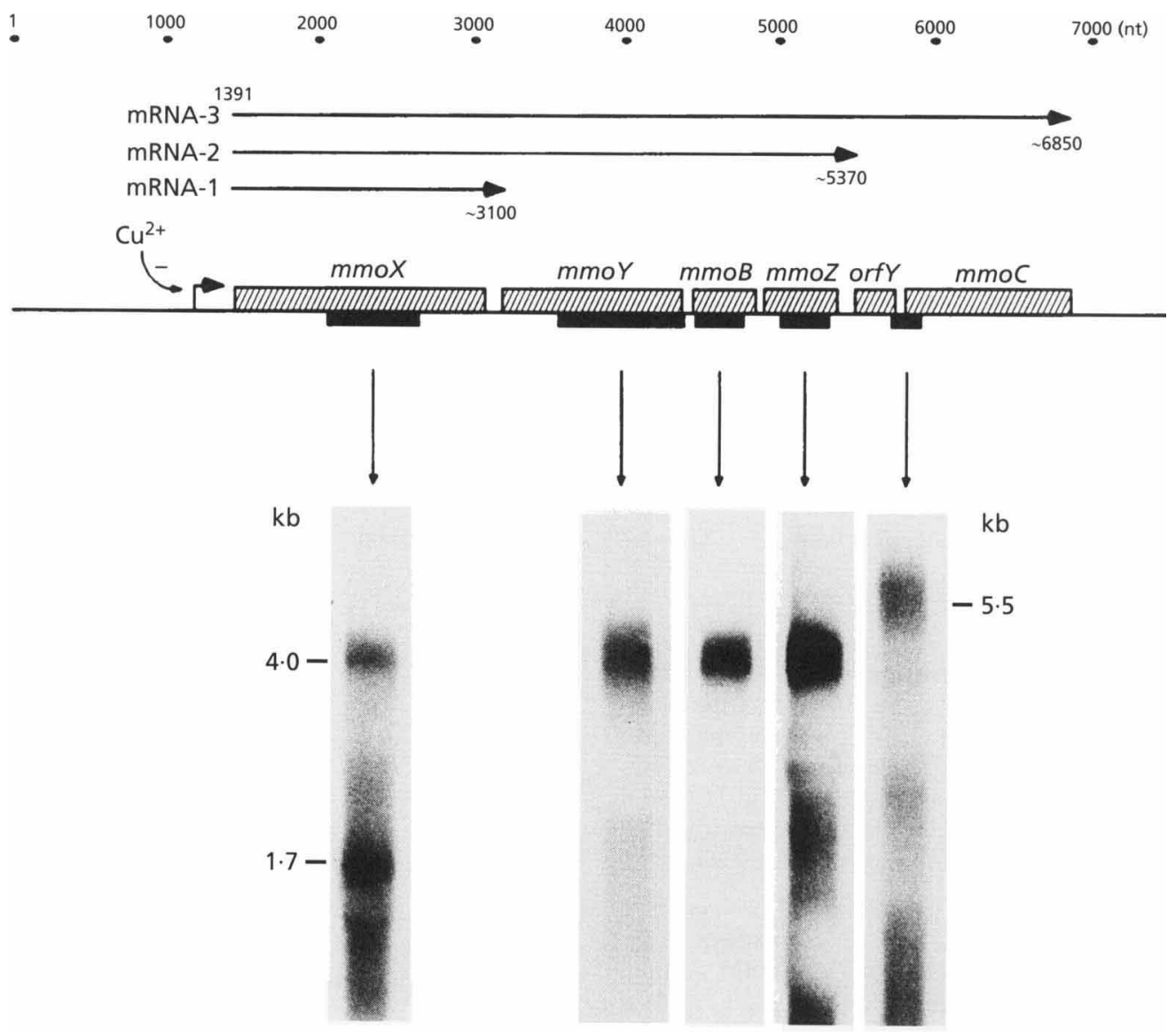

Fig. 1. Organization of the smmo operon (Stainthorpe et al., 1990), origin of the smmo antisense riboprobes and identification of smmo transcripts. ORFs of the smmo operon are indicated with hatched boxes and DNA fragments used for construction of probe plasmids are indicated by black boxes below the sMMO gene cluster (see also Table 1). Messenger RNAs are indicated with arrows pointing in the $5^{\prime}-3^{\prime}$ direction. The $5^{\prime}$ end is located at nucleotide 1391 and the approximate termination points are indicated at the end of each mRNA. The (not precisely defined) copper-regulated promoter region is indicated upstream of mmoX. ${ }^{32} \mathrm{P}$-labelled antisense riboprobes were transcribed from the probe plasmids and used to generate the Northern blots shown below the vertical arrows. The molecular mass standard was a commercial RNA ladder (Gibco BRL).

exhibited homology to this probe (Fig. 1). We designated these transcripts mRNA-1 and mRNA-2, respectively. Assuming that there was transcription of the smmo gene cluster from a promoter not far upstream $\left(5^{\prime}\right)$ of the $m$ moX gene, mRNA-1 may encode the mmoX gene product alone, and mRNA-2 may encode the mmoX, mmoY, $m m o B$ and $m m o Z$ gene products on one polycistronic mRNA.

This is consistent with the results obtained when the $m m o Y-, m m o B-$ and $m m o Z$-specific gene probes were used to probe $M$. capsulatus (Bath) total RNA: each of these gene probes only hybridized to one transcript of approximate size $4.0 \mathrm{~kb}$, which we believe is identical to mRNA-2 (Fig. 1). Upon lengthy over-exposure of the autoradiographs, a faint band of approximate size 5.5$6.0 \mathrm{~kb}$ was detectable (not visible in Fig. 1). This may be a full-length transcript encoding the gene products of the entire sMMO gene cluster (see below). We designated this transcript mRNA-3.
M. capsulatus (Bath) total RNA, however, when hybridized to the orf $Y-m m o C$-specific gene probe clearly yielded a transcript of approximately $5 \cdot 5-6.0 \mathrm{~kb}$ (Fig. 1). This mRNA had the same mobility on $1.2 \%$ agarose gels as the weakly detectable mRNA-3 described above and, taken together with the primer extension analysis described below, we believe that these transcripts are identical.

Thus, transcription of the sMMO gene cluster appears to be initiated from a single promoter upstream of the $m m o X$ gene.

\section{Transcription of the sMMO gene cluster is copper- regulated}

While it has been firmly established that increasing the amount of copper in the growth medium of $M$. capsulatus (Bath) induces the expression of pMMO and irreversibly inhibits the activity of the sMMO complex (Stanley $e t a l$., 


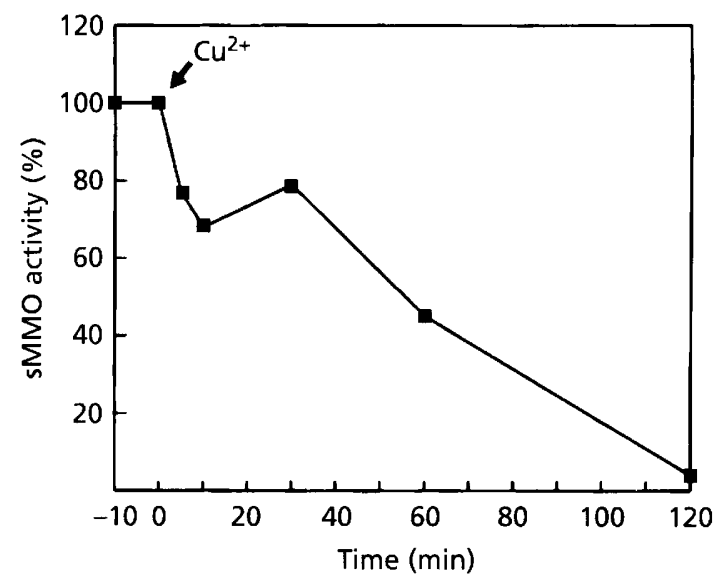

Fig. 2. The effect of copper addition to a chemostat culture of $M$. capsulatus (Bath). A steady-state culture of the organism was established on NMS medium at $D=0.05 \mathrm{~h}^{-1}$ with no added copper in the NMS medium. Copper sulphate was then added to a final concentration of $50 \mu \mathrm{M}$, at time zero, directly into the culture and samples were removed for RNA isolation and sMMO activity determination.

1983; Dalton et al., 1984; Prior \& Dalton, 1985), the role of copper at the level of transcription still remains to be clarified. We therefore investigated the effect of copper ions on the transcription of the smmo gene cluster by adding copper ions to an sMMO-expressing culture of $M$. capsulatus (Bath). Actively growing sMMO-expressing cells [as determined by the ability of cells to oxidize naphthalene to naphthols (pMMO does not oxidize naphthalene) which can then be detected in a colorimetric assay (Brusseau et al., 1990)] were maintained in a copperdepleted chemostat. Copper ions were added to a final concentration of $50 \mu \mathrm{M}$, and samples were harvested before and at several time points after addition. The relative sMMO activity in the different samples was determined spectrophotometrically by measuring their ability to oxidize naphthalene.

The effect of copper ions on whole cell sMMO activity, as revealed by this experiment, is seen in Fig. 2. Sixty minutes after the addition of copper, the sMMO activity decreased to $50 \%$, and after $120 \mathrm{~min}$, the activity was only a few percent of the initial level (i.e. before the addition of copper).

To investigate if the cells responded to the copper treatment by switching off the transcription of the sMMO gene cluster, total RNA was isolated from the samples described above and used in Northern blot experiments. When the mmoX-specific gene probe was used to probe total RNA isolated from $M$. capsulatus (Bath) before and after the addition of copper, the levels of mRNA-1 and mRNA-2 were found to decrease with a half-life of 5-10 min (Fig. 3a). The disappearance of mRNA-2 was further visualized by probing of the RNA samples with the mmoY-, mmoB- and mmoZ-specific gene probes. As seen in Fig. 3(b), the copper-induced reduction in the (a)

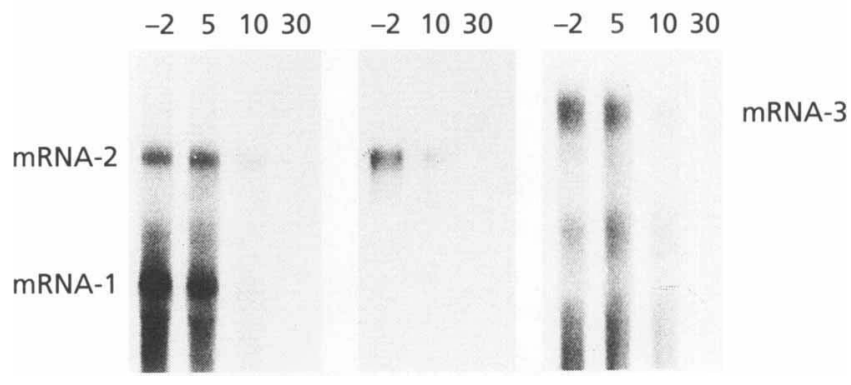

Fig. 3. Northern analysis of the sMMO mRNAs before and after addition of copper sulphate. Time-points of sampling are indicated above each lane (min). mRNA-1, mRNA-2 and mRNA-3 are described in Fig. 1. (a) RNA probed with mmoX; (b) RNA probed with $m m o B$; (c) RNA probed with orfY-mmoC. The molecular mass standard was a commercial RNA ladder (Gibco $B R L$ ). The riboprobes used were generated using T7 RNA polymerase with (a) plasmid pMX2, (b) plasmid pMB1 and (c) plasmid pMC2 (Aatll-digested) as templates.

level of smmo transcripts was also confirmed in these experiments (since the results of $m m o Y, m m o B$ and $m m o Z$ probings were identical, only the $m m o B$ probing is shown).

Data presented above suggested that the transcription of the three smmo-specific mRNAs is initiated from the same promoter upstream of the mmoX gene. Fig. 3(c) shows the result of an orf $Y-m m o C$-specific probing of total RNA isolated from $M$. capsulatus before and after addition of copper sulphate. As expected, this transcript also disappeared within a similar time scale after addition of copper ions.

\section{Primer extension analysis of sMMO mRNAs}

To determine the exact location of the 5 ' ends of the sMMO transcripts, primer extension analysis was carried out on M. capsulatus (Bath) total RNA samples extracted from cells taken before and after addition of copper sulphate. The primer Xp1 (see Methods for sequence) was used to direct the synthesis of complementary cDNA in the region immediately upstream of $m m o X$. When total RNA isolated from the copper-depleted chemostat culture of $M$. capsulatus (Bath) was used as template for reverse transcriptase, a unique extension product was obtained (Fig. 4, lane 2), This extension product mapped to nucleotide $\mathrm{C}_{1391}$ which is located 87 nucleotides upstream of the mmoX start codon. No extension products were detected, however, when total RNA isolated from $M$. capsulatus (Bath) cells taken after addition of copper sulphate to the chemostat were used as templates for cDNA synthesis (Fig. 4, lanes 10 and 30). Since no obvious similarities to other known promoters are found just upstream of $\mathrm{C}_{1391}$, this $5^{\prime}$ end could either result from trimming of a longer transcript or from transcriptional initiation at this site. No specific $5^{\prime}$ ends were found, however, when the primer extension experiments were performed with four different primers which anneal 


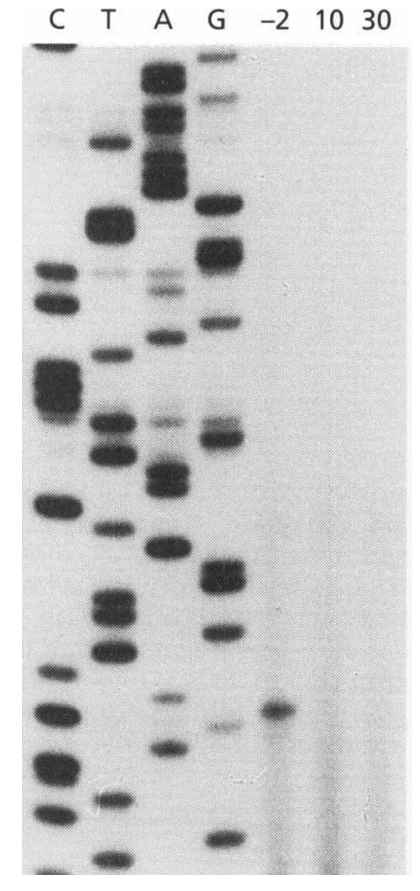

Fig. 4. Primer extension analysis. RNA isolation and primer extension were carried out as described in Methods. The primer used (Xp1-see Methods for sequence) is homologous to nucleotides $1422-1440,37 \mathrm{bp}$ upstream of the mmoX start codon. RNA was isolated from samples taken before and after the addition of copper sulphate. Time points of sampling after addition of copper sulphate are indicated above each lane (min). The nucleotide sequence ladder was obtained by sequencing of plasmid $\mathrm{pCH} 4$ using the $\mathrm{Xp} 1$ primer.

further upstream of Xp1 (data not shown). The primers used were Xp2, Xp3, Xp4 and Xp5 (see Methods for sequences).

Intergenic regions between $m m o X$ and $m m o Y$ and between $m m o Z$ and $o r f Y$ are of sizes that would allow the presence of promoter elements without interfering with the expression of the adjacent genes (Stainthorpe et al., 1989, 1990). For this reason, and to complement the Northern analysis, primer extension analyses were performed using primers complementary to these regions. The primers Yp1 and orfYp1 (see Methods for sequences) are complementary to the regions immediately downstream of the mmo $Y$ and $\operatorname{orf} Y$ start codons, respectively, and when cDNA synthesis was directed by these primers, no extension products were detected (data not shown). Nor was an extension product obtained when an $m m o C$-specific primer (MC5781, see Methods) was used in an identical experiment (data not shown). Hence, the data obtained in the primer extension experiments are consistent with the Northern analyses.

\section{DISCUSSION}

Previous reports on DNA sequence analysis of the sMMO gene cluster of $M$. capsulatus (Bath) have shown that the genes encoding the components of sMMO are all linked on the chromosome in the order mmoX, mmoY, mmoB, $m m o Z$, orf $Y$ and $m m o C$. Intercistronic regions were found to be relatively small, the largest are located between $m m o X$ and mmoY (78 bp) and between mmoZ and orf $Y$ (155 bp) (Stainthorpe et al., 1989, 1990). Only the mmoX gene was found to be preceded by putative promoter sequences showing homology to $E$. coli -35 and -10 consensus sequences. Weak homology to the -12 and -24 promoter elements of Pseudomonas (Deretic et al., $1987)$ and to $n i f-$ and $n t r-(R p o N)$ like promoters (Dixon et al., 1986) was also found in this region. Since it has been extremely difficult to obtain high quality mRNA samples from methanotrophs, previous attempts to identify smmospecific transcripts were unsuccesful (J.C. Murrell and others, unpublished results).

Using Northern blot and primer extension analyses, we undertook a closer examination of the RNAs produced from the sMMO gene cluster. Primer extension analysis of four regions likely to contain promoter elements (i.e. upstream of $m m o X$, between $m m o X$ and $m m o Y$, between $m m o Z$ and $\operatorname{orf} Y$, and within $\operatorname{orf} Y$ ) indicated that transcription is initiated from a single promoter located 87 nucleotides upstream of the mmoX start codon. No specific $5^{\prime}$ ends were found in other regions investigated in this study. A background of non-specific cDNAs, probably due to premature stops by reverse transcriptase, was obtained when primers complementary to regions downstream of the mmoX ORF were used. This indicates that a target for the smmo-specific primers was present (i.e. smmo-specific mRNA) but the $5^{\prime}$ end was too far upstream to be reached by reverse transcriptase or simply too large to be seen on a sequencing gel.

The Northern analyses yielded three transcripts apparently differing only in their $3^{\prime}$ ends: mRNA-1 encoding $m m o X$; mRNA-2 encoding $m m o X, m m o Y, m m o B$ and $m m o Z$; and mRNA-3 encoding all the mmo cistrons. Whether mRNA-1 and mRNA-2 originates from endonucleolytic cleavage of mRNA-3 or from transcriptional termination events is at present unknown. However, motifs resembling $\rho$-independent transcriptional terminators are present in the mmoX/mmoY $\left(\mathrm{T}_{1}\right)$ and mmoZ/orf $Y\left(\mathrm{~T}_{2}\right)$ intercistronic regions (Stainthorpe et al., 1989).

To investigate the role, if any, of copper ions in transcriptional regulation of the sMMO gene cluster, we followed the pattern of smmo-specific mRNAs after addition of copper to a copper-depleted culture. We found that the level of smmo-specific mRNAs in $M$. capsulatus (Bath) decreased in response to the sudden availability of copper ions when all the other growth parameters (e.g. pH, oxygen, methane and nitrogen) were constant. This important observation may indicate that transcription of the smmo genes is specifically repressed by copper ions. Since the growth of the cells was unaffected by the copper treatment and no general RNA degradation was observed (as visualized on agarose gels), it is likely that a specific inhibition of the smmo promoter was provoked by the sudden availability of copper ions. Posttranscriptional control, however, such as copper-dependent changes in stability of sMMO mRNAs, cannot be ruled out at this stage. 
We also investigated the effect of copper ions on wholecell sMMO activity. As revealed in Fig. 2, the copper treatment resulted in loss of sMMO activity, although the time taken for this negative effect of copper on sMMO was a little delayed compared to earlier reports (Green $e t$ al., 1985). Whether this loss of sMMO activity was due to specific inhibition of the enzyme or simply due to protein turnover cannot be ruled out from our data.

The molecular mechanism by which copper ions regulate the smmo promoter is not yet understood. Metal ions have, however, in several cases been identified as cofactors in the regulation of bacterial gene expression. The metal ions act via receptor proteins, which, upon binding of the metal, become activated as transcriptional repressors or activators. This kind of regulation has been described for a number of iron assimilation genes in E. coli. In this organism, transcription of genes involved in iron uptake is under the negative control of a regulator protein called Fur (reviewed in Silver \& Walderhaug, 1992). In the presence of divalent ferrous ions, Fur recognizes and binds to operator sequences located in promoters of ironregulated genes, preventing transcription. When the iron concentration drops, the Fur-iron complex dissociates resulting in derepression of the genes (de Lorenzo et al., 1987).

Copper ions might act on the smmo promoter via such a receptor protein according to the following model. The RNA polymerase transcribes the smmo genes in the absence of copper ions. When copper ions are abundant, however, it complexes with the transcriptional regulator which then becomes capable of binding to an operator sequence in the smmo promoter region. Consequently, transcription of the smmo genes is repressed. We cannot, however, exclude the possibility that copper ions inactivate a transcriptional activator of the smmo promoter. This is the first example of a metal-regulated promoter in methanotrophs and may provide a valuable tool for gene expression in these ecologically important organisms. The molecular basis for copper-mediated gene regulation in methanotrophic bacteria warrants further study, although this may prove difficult in a group of bacteria for which there are few genetic systems (Murrell, 1992).

In conclusion, our results imply that the six ORFs of the sMMO gene cluster are organized as an operon transcribed by a single copper-regulated promoter upstream of mmoX.

\section{ACKNOWLEDGEMENTS}

This work was supported by a grant from the Danish Center for Process Biotechnology.

\section{REFERENCES}

Anthony, C. (1986). Bacterial oxidation of methane and methanol. Adv Microb Pbysiol 27, 113-210.

Bolivar, F., Rodrigues, R. L., Greene, P. J., Betlach, M. C., Heyneker, H. L., Boyer, H. W., Crosa, J. H. \& Falkow, S. (1977). Construction and characterization of new cloning vehicles. II. A multipurpose cloning system. Gene 2, 95-113.

Brusseau, G. A., Tsien, H.-C., Hanson, R. S. \& Wackett, L. P. (1990).
Optimization of trichloroethylene oxidation by methanotrophs and the use of a colorimetric assay to detect soluble methane monooxygenase activity. Biodegradation 1, 19-29.

Cardy, D. L. N., Laidler, V., Salmond, G. P. C. \& Murrell, J. C. (1991a). Molecular analysis of the methane monooxygenase (MMO) gene cluster of Metbylosinus trichosporium OB3b. Mol Microbiol 5, $335-342$.

Cardy, D. L. N., Laidler, V., Salmond, G. P. C. \& Murrell, J. C. (1991b). The methane monooxygenase gene cluster of Metbylosinus trichosporium: cloning and sequencing of the mmoC gene. Arch Microbiol 156, 477-483.

Chan S. I., Nguyen, H.-H. T., Shiemke, A. K. \& Lidstrom, M. E. (1993). Biochemical and biophysical studies towards characterization of the membrane-associated methane monooxygenase. In Microbial Growth on $C_{1}$ Compounds, pp. 93-107. Edited by J. C. Murrell \& D. P. Kelly. Andover: Intercept Press.

Colby, J. \& Dalton, H. (1978). Resolution of the methane monooxygenase of Methylococcus capsulatus (Bath) into three components. Biochem J 171, 461-468.

Colby, J. \& Dalton, H. (1979). Characterization of the second prosthetic group of the flavoenzyme NADH-acceptor reductase (component C) of the methane monooxygenase from Metbylococcus capsulatus (Bath). Biochem J 157, 495-497.

Dalton, H. \& Whittenbury, R. (1976). The acetylene reduction technique as an assay for the nitrogenase activity in the methaneoxidizing bacterium Metbylococcus capsulatus strain Bath. Arch Microbiol 109, 147-151.

Dalton, H., Prior, S. D., Leak, D. J. \& Stanley, S. (1984). Regulation and control of methane monooxygenase. In Microbial Growth on $C_{1}$ Compounds. Proceedings of the 4th International Symposium, pp. 75-82. Edited by R. L. Crawford \& R. S. Hanson. Washington, DC: American Society for Microbiology.

Dalton, H., Wilkins, P. \& Jiang, Y. (1993). Structure and mechanism of action of the hydroxylase of soluble methane monooxygenase. In Microbial Growth on $C_{1}$ Compounds, pp. 65-80. Edited by J. C. Murrell \& D. P. Kelly. Andover: Intercept Press.

Deretic, V., Gill, J. F. \& Chakrabarty, A. M. (1987). Alginate biosynthesis: a model system for gene regulation and function in Pseudomonas. Biotechnology 5, 469-477.

Dixon, R. (1986). The $x y l A B C$ promoter from the Pseudomonas putida TOL plasmid is activated by nitrogen regulatory genes in Eschericbia coli. Mol Gen Genet 203, 129-136.

Fox, B. G., Froland, W. A., Dege, J. E. \& Lipscomb, J. D. (1989). Methane monooxygenase from Metbylosinus tricbosporium OB3b. Purification and properties of a three-component system with high specific activity from a type II methanotroph. $J$ Biol Chem 264, 10023-10033.

Fox, B. G., Froland, W. A., Jollie, D. R. \& Lipscomb, J. D. (1990). Methane monooxygenase from Metbylosinus trichosporium OB3b. Metbods Enzymol 188, 191-202.

Fox, B. G., Lin, Y., Dege, J. E. \& Lipscomb, J. D. (1991). Complex formation between the protein components of methane monooxygenase from Metbylosinus trichosporium OB3b, identification of sites of component interaction. J Biol Chem 266, 540550.

Green, J. \& Dalton, H. (1985). Protein B of the soluble methane monooxygenase from Metbylococcus capsulatus (Bath): a novel regulatory protein of enzyme activity. $J$ Biol Chem 260, 15795-15801.

Green, J., Prior, S. D. \& Dalton, H. (1985). Copper ions as inhibitors of protein $\mathrm{C}$ of soluble methane monooxygenase Methylococcus capsulatus (Bath). Eur J Biochem 153, 137-144.

Koh, S.-C., Bowman, J. P. \& Sayler, G. S. (1993). Soluble methane 
monooxygenase production and trichlorethylene degradation by a type I methanotroph, Metbylomonas methanica 68-1. Appl Environ Microbiol 59, 960-967.

Lipscomb, J. D. (1994). Biochemistry of the soluble methane monooxygenase. Annu Rev Microbiol 48, 371-399.

Liu, K. E. \& Lippard, S. J. (1991). Redox properties of the hydroxylase component of methane monooxygenase from Metbylococcus capsulatus (Bath): effects of protein B, reductase and substrate. J Biol Chem 266, 12836-12839.

de Lorenzo, V., Wee, S., Herrero, M. \& Nielands, J. B. (1987). Operator sequences of the aerobactin operon of plasmid ColV-K30 binding the ferric uptake regulation (fur) repressor. J Bacteriol 169, 2624-2630.

Lund, J. \& Dalton, H. (1985). Further characterization of the FAD and $\mathrm{Fe}_{2} \mathrm{~S}_{2}$ redox centres of component $\mathrm{C}$, the NADH:acceptor reductase of the soluble methane monooxygenase of Metbylococcus capsulatus (Bath). Eur J Biochem 147,291-296.

Lund, J., Woodland, M. P. \& Dalton, H. (1985). Electron transfer reactions in the soluble methane monooxygenase of Methylococcus capsulatus (Bath). Eur J Biochem 147, 297-305.

Maniatis, T., Fritsch, E. F. \& Sambrook, J. (1982). Molecular Cloning: a Laboratory Manual. Cold Spring Harbor, NY: Cold Spring Harbor Laboratory.

Miller, J. (1972). Experiments in Molecular Genetics. Cold Spring Harbor, NY: Cold Spring Harbor Laboratory.

Murrell, J. C. (1992). Genetics and molecular biology of methanotrophs. FEMS Microbiol Rev 88, 233-248.

Murrell, J. C. (1994). Molecular genetics of methane oxidation. Biodegradation 5, 145-159.

Nakajima, T., Uchiyama, H., Yagi, O., Nakahara, T. (1992). Purification and properties of a soluble methane monooxygenase from Methylocystis sp. M. Biosci Biotech Biochem 56, 736-740.

Nguyen, H.-H. T., Shiemke, A. K., Jacobs, S. J., Hales, B. J., Lidstrom, M. E. \& Chan, S. I. (1994). The nature of the copper ions in the membranes containing the particulate methane monooxygenase from Methylococcus capsulatus (Bath). J Biol Chem 269, 14995-15005.

Pilkington, S. J. \& Dalton, H. (1991). Purification and characterization of the soluble methane monooxygenase from Methylosinus sporium 5 demonstrates the highly conserved nature of this enzyme in methanotrophs. FEMS Microbiol Lett 78, 103-108.
Prior, S. D. \& Dalton, H. (1985). The effect of copper ions on membrane content and methane monooxygenase activity in methanol-grown cells of Methylococcus capsulatus (Bath). J Gen Microbiol 131, 155-163.

Sanger, F., Nicklen, S. \& Coulsen, A. R. (1977). DNA sequencing with chain terminating inhibitors. Proc Natl Acad Sci USA 74, 5463-5467.

Scott, D., Brannan, J. \& Higgins, I. J. (1981a). The effect of growth conditions on intracytoplasmic membranes and methane monooxygenase activities in Metbylosinus trichosporium OB3b. $J$ Gen Microbiol 125, 63-72.

Scott, D., Best, D. J. \& Higgins, I. J. (1981b). Intracytoplasmic membranes in oxygen-limited chemostat cultures of Methylosinus trichosporium OB3b: biocatalystic implication of physiologically balanced growth. Biotecbnol Lett 3, 641-644.

Silver, S. \& Walderhaug, M. (1992). Gene regulation of plasmidand chromosome-determined inorganic ion transport in bacteria. Microbiol Rev 56, 195-228.

Stainthorpe, A. C., Murrell, J. C., Salmond, G. P. C., Dalton, H. \& Lees, V. (1989). Molecular analysis of methane monooxygenase from Metbylococcus capsulatus (Bath). Arch Microbiol 152, 154-159.

Stainthorpe, A. C., Lees, V., Salmond, G. P. C., Dalton, H. \& Murrell, J. C. (1990). The methane monooxygenase gene cluster of Metbylococcus capsulatus (Bath). Gene 91, 27-34.

Stanley, S. H., Prior, S. D., Leak, D. J. \& Dalton, H. (1983). Copper stress underlies the fundamental change in intracellular location of methane monooxygenase in methane-oxidizing organisms: studies in batch and continuous cultures. Biotechnol Lett 5, 487-492.

Stirling, D. I. \& Dalton, H. (1979). Properties of the methane monooxygenase from extracts of Methylosinus trichosporium OB3b and evidence for its similarity to the enzyme from Metbylococcus capsulatus (Bath). Eur J Biochem 96, 205-212

Tsien, H.-C., Brusseau, G. A., Hanson, R. S. \& Wacket L. P. (1989). Biodegradation of trichlorethylene by Metbylosinus trichosporium OB3b. Appl Environ Microbiol 55, 3155-3161.

Woodland, M. P. \& Dalton, H. (1989). Purification and characterization of Component $A$ of the methane monooxygenase from Metbylococcus capsulatus (Bath). J Biol Chem 259, 53-59.

Received 20 June 1995; revised 16 November 1995; accepted 19 December 1995. 